\title{
MENJADI FOTOGRAFER DENGAN KAMERA SEDERHANA
}

\author{
Agnes Paulina Gunawan \\ Jurusan Desain Komunikasi Visual, Fakultas Komunikasi dan Multimedia, \\ Bina Nusantara University, Jln. KH Syahdan No. 9, Palmerah, Jakarta Barat 11480 \\ agunawan@binus.edu
}

\begin{abstract}
With the advanced technology in this era, everybody must be quite familiar with the use of camera to take pictures, with different types of SLR camera or pocket camera, digital or manual, with very economic pricing to the most expensive ones, and even the camera which has become one of the features in cell phone. Eventhough there is a very easy access to photography, if one photographer does it without enough knowledge and technique of good photography, sometimes he will not be satisfied with the results. It will be best if a photographer understands a bit of the theories, so he can anticipate any problems which are sometimes caused by the limited features in some not so advanced cameras. And with several tips and tricks of the basic understanding in photography, he will be able to avoid such issues.
\end{abstract}

Keywords: basic technique of photography, tips and tricks to take a picture, how to take photo with prosumer camera

\begin{abstract}
ABSTRAK
Dengan kemajuan tehnologi yang sangat pesat dijaman ini, semua orang pasti cukup familiar dengan penggunaaan kamera dalam memotret, baik dengan beragam jenis kamera SLR dan kamera saku, dengan yang digital maupun manual, dari harga yang sangat ekonomis maupun yang sangat mahal, hingga kamera yang menjadi fitur dalam kamera telpon genggam. Dengan akses yang begitu mudah dalam memotret, namun tanpa disertai ilmu dan tehnik fotografi yang memadai, mungkin akan muncul beberapa masalah dalam hasil pemotretan yang tidak sesuai dengan hasil yang diinginkan oleh si fotografer. Sehingga akan lebih mudah bila fotografer tersebut bisa memahami sedikit teori fotografi, sehingga bisa mengantisipasi permasalahanpermasalahan tersebut terutama karena keterbatasan fitur dalam kamera-kamera yang sederhana. Dan dengan beberapa kiat dan saran sesuai tehnik dasar fotografi, fotografer dapat menghindari masalah-masalah tersebut.
\end{abstract}

Kata kunci: tehnik fotografi dasar, kiat dan saran dalam memotret, memotret dengan kamera sederhana 


\section{PENDAHULUAN}

Semua orang bisa memotret. Beberapa tahun yang lalu bila mendengar kalimat tersebut, mungkin tidak semua orang setuju dengan pernyataan itu karena tidak banyak orang mempunyai kamera untuk memotret. Namun pernyataan tersebut pasti dapat diterima saat ini, dengan banyaknya kamera digital baik yang kamera saku ataupun SLR (Single Lens Reflect) dengan variasi harga yang cukup terjangkau di kalangan umum, maupun kamera yang menjadi salah satu fitur andalan hampir di semua tipe telpon genggam, di semua merk yang beredar saat ini.

Dengan kenyataan tersebut sangatlah mungkin semua orang bisa memotret, karena proses pemotretan digital ini sangatlah sederhana, cepat dan mudah. Tanpa harus bersusah-susah membeli film dahulu, tanpa harus mengerti tehnik fotografi, tanpa harus memproses dan mencetak film supaya hasil foto dapat dinikmati, tinggal membidik objek yang ingin difoto, jepret, maka foto tersebut langsung dapat dilihat hasilnya baik di layar telpon genggam, atau di layar kamera digital atau dipamerkan kepada teman dan keluarga dengan di-upload melalui Blackberry messenger, melalui Facebook, atau Twitter dan sebagainya.

Namun bagaimana dengan pernyataan semua orang bisa memotret dengan hasil yang bagus? Apakah semua hasil jepretan tadi pasti menghasilkan foto yang artistik atau foto yang indah? Untuk sebagian orang yang pernah memotret, tanpa pernah belajar tentang komposisi atau tehnik pencahayaan dalam fotografi, mungkin tidak terlalu setuju dengan pernyataan tersebut. Mungkin sebagian dari mereka memiliki pengalaman mendapat hasil foto yang gelap, objeknya buram, atau objeknya terekam tapi tidak fokus karena goyang, atau mungkin foto dengan hasil warna yang tidak sesuai dengan aslinya.

Mungkin dengan beberapa penjelasan berikut, sebagian dari permasalahan tersebut dapat dianalisa penyebabnya serta dapat dihindari agar foto yang dihasilkan bisa lebih baik dan lebih terkontrol hasilnya sesuai dengan harapan si pemotret pada saat mengabadikan momen tersebut, tanpa harus menjadi seorang fotografer profesional dahulu.

\section{METODE PENELITIAN}

Penulisan ini disusun sebagai hasil dari penelitian kualitatif dengan pendekatan melalui metode studi literatur berdasarkan pengumpulan data melalui buku-buku dan sumber dari internet mengenai teori-teori dasar fotografi yang berkaitan dengan materi pembahasan. Serta dari hasil analisa dari studi kasus beberapa forum tanya jawab mengenai permasalahan umum yang paling sering dilontarkan oleh fotografer awam serta dari hasil pengamatan dari hasil foto-foto amatir dari orang yang bukan fotografer dalam beberapa situs jaringan sosial.

\section{HASIL DAN PEMBAHASAN}

\section{Tentang Fotografi}

Walaupun banyak yang telah sering menyebut dan mengetahui tentang kata fotografi, mungkin belum semua mengerti, apa sebenarnya fotografi itu sendiri. Fotografi dari bahasa Latin photos dan graphos. Photos berarti cahaya dan graphos berarti gambar. Sebagian lain dalam teori menyebutkan bahwa fotografi adalah 'painting with light' atau melukis dengan cahaya. Dari pernyataan tersebut, dapat dipahami bahwa aspek yang harus ada dalam fotografi sendiri adalah 
keberadaan cahaya, tanpa cahaya seorang fotografer tidak akan bisa memotret. Karena cahaya tadi jatuh mengenai objek dan dipantulkan ke dalam kamera, maka terekamlah bentuk dari objek tersebut didalam sebuah foto.

Bahkan ada pendapat bahwa apa yang dilakukan dalam fotografi adalah mengubah bentuk dari alam 3 (tiga) dimensi yang dilihat secara visual ini ke dalam sebuah bidang datar 2 (dua) dimensi yang dibatasi ujung-ujung kertas foto. Istilah ini akan mudah dipahami melihat proses dari beberapa foto yang mungkin pernah menjadi koleksi teman atau keluarga, misalnya saat seseorang mengagumi pemandangan disuatu tempat atau saat ada sekelompok teman dekat, dan ada yang ingin mengabadikannya dengan kamera telpon genggam, saat itu yang terjadi adalah sang fotografer merekam suatu tempat atau kejadian yang disukai dan ingin disimpan dalam memori. Maka berdasarkan kejadian tersebut bagian yang secara visual dilihat dan disukai seseorang, bisa disimpan dalam bentuk 2 dimensi dalam sebuah bidang foto.

Dalam sebuah situs yang membahas tentang fotografi, disebutkan juga bahwa yang dilakukan dalam fotografi adalah membekukan waktu melalui lensa. Sedangkan disitus itu disebutkan bahwa seorang fotografer pada dasarnya merekam suatu kegiatan yang tidak akan dimakan waktu. Oleh karena itu, selembar karya foto bisa disebut sebagai selembar 'kenangan'.

Namun bila membahas tentang bagaimana menghasilkan foto yang bagus, pada dasarnya tidak ada suatu ketentuan atau syarat khusus, tetapi yang paling menarik dari memotret adalah adanya kejutan dari hasil foto bila sesekali fotografer memotret suatu posisi dari suatu sudut yang tidak umum. Tapi setiap pemandangan yang dapat dilihat secara visual dan nyata pasti berbicara lebih banyak dibanding selembar kertas atau sebuah bidang yang hanya berbentuk 2 (dua) dimensi tersebut, sehingga disaat inilah dibutuhkan kemampuan fotografer untuk mengabadikan semaksimal mungkin apa yang dilihatnya tadi supaya hasil fotonya bisa menyampaikan apa yang telah dilihat semirip mungkin, bahkan menghasilkan foto yang menarik dan bagus.

\section{Tentang Tombol Kontrol Kamera}

Kamera modern yang saat ini banyak digunakan, didesain untuk dapat dipakai oleh semua orang. Tombol kontrol yang terdapat pada kamera, makin sederhana dan makin berkurang fitur-fitur pengaturannya. Tinggal pencet satu tombol, tanpa harus mengubah atau mengatur sesuatu, pasti bisa menghasilkan foto. Sehingga pada saat memotret banyak dari pengguna kamera-kamera itu tidak perlu dipusingkan dengan tombol pengaturan lama pemotretan, atau berapa banyaknya cahaya yang dibutuhkan saat pemotretan, namun tetap mendapatkan hasil foto yang cukup normal dalam pencahayaannya.

Yang masih umum didapati adalah tombol pengaturan lensa zoom, untuk mengubah sudut pengambilan objek dalam foto, mau tampak luas untuk memotret interior dengan lensa wide, atau mau objek yang jauh tampak lebih dekat dengan lensa tele. Namun tidak semua kemudahan tersebut bisa menjamin seorang fotografer pasti mendapat hasil sesuai keinginannya. Sebelum membahas lebih lanjut tentang bagaimana menghasilkan foto yang sesuai keinginan fotografer, akan lebih mudah mengetahui terlebih dahulu bagaimana sistem kerja sebuah kamera, sehingga lebih mudah untuk menganalisa situasi dan masing-masing fotografer bisa mengatasinya semua kondisi di lapangan supaya bisa menghasilkan karya maksimal sesuai keinginannya saat pengambilan momen foto tersebut.

Idealnya pada sebuah kamera seharusnya ada 2 (dua) kontrol yang memiliki fungsi yang berbeda namun selalu bekerja bersamaan, untuk dapat menghasilkan foto yang normal pencahayaannya. Kontrol yang pertama adalah bukaan diafragma, yaitu bagian yang merupakan tempat (lubang) masuknya cahaya menuju kamera, diafragma ini dapat diatur besar kecil lubangnya, sehingga bisa mengatur banyak atau sedikitnya cahaya yang masuk kedalam kamera. 
Kontrol yang kedua adalah kecepatan rana (atau yang lebih umum disebut sebagai shutter speed), yaitu bagian yang mengatur kecepatan diafragma saat membuka dan menutup, sehingga menentukan seberapa lama atau seberapa cepatnya cahaya masuk melalui diafragma yang terbuka, ke dalam kamera. Fungsi kedua kontrol tersebut untuk mengatur banyaknya cahaya yang masuk kedalam kamera untuk menghasilkan foto dengan pengukuran cahaya senormal mungkin.

Pada dasarnya foto yang membutuhkan cahaya pada proses perekamannya, pasti memiliki ukuran atau takaran untuk menentukan seberapa banyak cahaya yang dibutuhkan supaya hasil foto yang dihasilkan memiliki takaran cahaya yang pas dan normal, tidak kekurangan cahaya atau terlalu gelap, dan juga tidak kelebihan cahaya atau terlalu terang. Biasanya pengukuran ini merupakan kombinasi antara berapa banyak jumlah cahaya yang akan menyinari foto dan berapa lama waktu cahaya tersebut masuk. Misalnya, saat ini fotografer melakukan pemotretan, maka yang terjadi saat fotografer menekan tombol adalah lubang diafragma kamera terbuka dengan waktu yang diatur oleh shutter speed.

Pengukuran ini bisa diatur dan disesuaikan bila kamera yang dipakai merupakan kamera SLR yang memiliki pengaturan manual. Namun fitur ini belum lazim terdapat dalam kamera saku atau kamera telpon genggam, yang memiliki pengaturan otomatis dalam pengukuran normal cahaya yang dibutuhkan. Sehingga hal ini yang menjadikan beberapa permasalahan timbul dalam pemotretan dengan kamera yang otomatis, yang akan dibahas berikut.

\section{Beberapa Masalah Umum dan Cara Mengatasinya}

'Objek yang difoto terlihat gelap, padahal latar belakangnya cukup terang'. Beberapa orang pernah mengalami kejadian ini, misalnya saat rekreasi bersama di daerah pantai, ada yang ingin berfoto dengan latar belakang saat matahari terbenam, saat dicek hasil fotonya ternyata semua model yang difoto terlihat gelap, padahal latar belakang matahari terbenamnya tetap indah dan terang. Atau saat jalan di mal, ingin memotret dengan latar belakang etalase toko yang terang, ternyata model atau objek fotonya malah terlihat gelap namun latar belakang tetap terang.

Bila hasil foto yang dihasilkan seperti di atas, sebenarnya yang terjadi adalah kondisi yang digunakan sebagai latar belakang tadi ternyata lebih terang dibandingkan cahaya yang jatuh pada model, dengan kata lain kamera mendapat sumber cahaya dari arah belakang objek, dalam fotografi keadaan ini disebut sebagai backlight. Dengan latar yang lebih terang, kamera mengukur normal foto tadi berdasarkan tingkat keterangan latar belakang tersebut, yang membuat kondisi model atau objek jadi terlihat lebih gelap. Semakin jauh perbedaan antara latar belakang dengan cahaya yang jatuh pada model maka kondisi model akan lebih gelap lagi. Dalam fotografi, kondisi tersebut dikenal dengan tehnik siluet, yaitu kondisi dimana sebuah foto akan kehilangan semua detail dari objek atau modelnya namun sebagai gantinya akan memiliki suatu bentuk unik yang kadang bisa membuat pengamat menerka-nerka atau berimajinasi dengan bentuk tersebut.

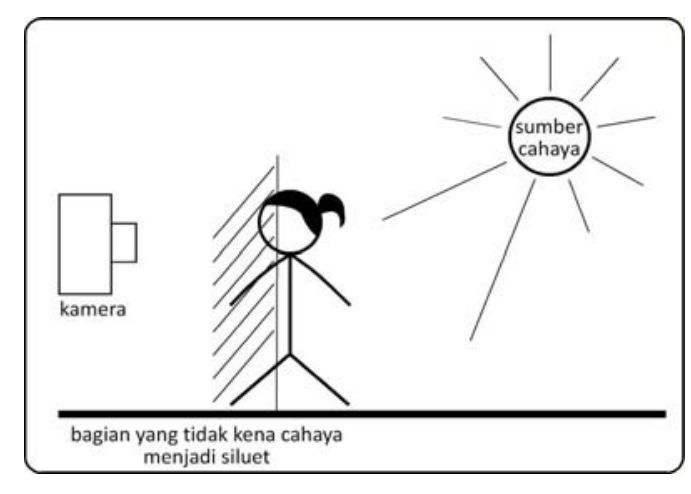

Gambar 1 Posisi Pencahayaan Backlight 
Namun bila fotografer tidak ingin menghasilkan foto siluet, yang harus dilakukan adalah mengisi bagian yang gelap pada objek tersebut dengan cahaya yang cukup terang dibanding latar belakangnya, dengan tujuan supaya pengukuran kamera bisa membaca cahaya pada objek tanpa perbedaan yang jauh dengan cahaya pada latar belakangnya. Sehingga bagian depan dan belakang memiliki kualitas cahaya yang sama terang.

Salah satu cara mengisi atau menambah cahaya pada bagian objek dengan cahaya tambahan, misalnya dengan build in flash yang sekarang merupakan fitur yang pasti ada dalam kamera saku digital, maupun di sebagian besar dari tipe telpon genggam yang beredar dipasaran. Atau bila perbedaan cahayanya tidak terlalu jauh, mungkin bisa diatasi dengan memberikan pantulan dari sebuah bidang putih atau yang berwarna terang sebagai pemantul agar objek dan model yang akan difoto terbantu mendapat pantulan cahaya sehingga bagian yang gelap tadi menjadi lebih terang. Cara lain yang pasti lebih berhasil lagi tentu saja dengan mengubah sudut pemotretan agar sumber cahaya tidak berada di belakang objek yang akan difoto, namun dengan cara ini pemandangan pantai bernuansa kuning kemerahan karena matahari terbenam tadi mungkin harus dilewatkan tanpa ada model di depannya.

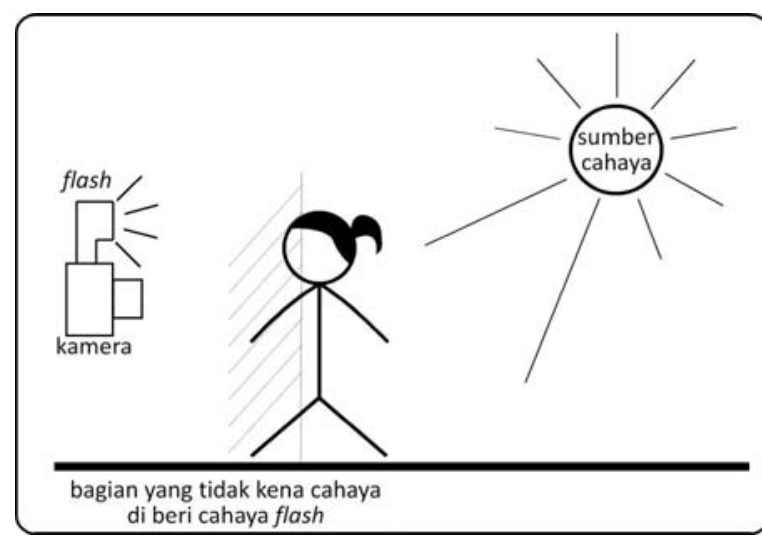

Gambar 2 Posisi Pencahayaan Backlight yang ditambah Cahaya Flash didepannya

'Objek yang difoto tidak fokus tetapi latar belakangnya fokus'. Beberapa orang juga pernah mengalami kejadian seperti ini, model atau objeknya terlihat buram namun latar di belakangnya terlihat cukup fokus dan jelas. Dalam hal ini ada dua kemungkinan yang mungkin terjadi saat pemotretan. Kemungkinan tersebut harus dianalisa terlebih dahulu dengan kondisi yang muncul dalam foto hasil pemotretan.

Kemungkinan pertama adalah bila hasil yang terfoto menampilkan model atau objek tersebut buram, terlihat besar dan cukup dekat jarak pengambilannya, serta umumnya sebagian besar frame foto terisi dengan si objek tersebut, maka kemungkinan yang terjadi dengan kondisi yang terfoto saat itu adalah objek tersebut berada terlalu dekat dengan lensa kamera pada saat pemotretan terjadi, sehingga dengan jarak tersebut semua objek tidak bisa fokus, karena lensa kamera memiliki jarak minimum agar objek didepannya bisa fokus.

Untuk lebih memahami kondisi tersebut akan lebih mudah bila seorang fotografer memahami karakter dari tipe lensa dalam fotografi. Lensa sudut lebar atau wide, merupakan lensa yang bisa memotret dengan bidang bagian yang lebih luas dari jarak pandang sebelah mata manusia pada umumnya. Biasanya jangkauan pemotretan yang luas membuat lensa ini dipakai untuk memotret interior, arsitektural atau bidang yang ingin terfoto dengan luas, contoh lensa ini adalah lensa yang 
memiliki focal length berukuran dibawah $50 \mathrm{~mm}$ seperti lensa $10-22 \mathrm{~mm}, 24 \mathrm{~mm}$, 35mm. Lensa tele, merupakan lensa dengan kemampuan membuat objek yang jauh terlihat lebih dekat dan terlihat lebih besar. Lebih sering dipakai dalam pemotretan model, pemotretan balap mobil, atau pemotretan yang objeknya berjarak cukup jauh dari fotografer, contoh lensa ini berukuran diatas 50mm: 70-200mm, $180 \mathrm{~mm}, 135 \mathrm{~mm}$. Lensa normal adalah lensa dengan bidang pandang yang sesuai dengan jarak pandang mata manusia pada umumnya, lensa normal ini berukuran antara $40-55 \mathrm{~mm}$. Lensa makro, merupakan lensa yang dapat memotret suatu benda dengan jarak yang cukup dekat dan fokus. Efek yang dihasilkan mampu menangkap detail suatu objek dari jarak dekat, biasanya dipakai untuk memotret benda yang kecil atau membutuhkan detail tekstur.

Setelah mengetahui beberapa informasi umum tentang tipe lensa yang tersebut diatas, maka dapat dianalisa penyebab objek foto tersebut tampak buram atau tidak fokus, karena tipe lensa yang digunakan dalam pemotretan bukan tipe lensa makro, sehingga karena jarak yang cukup dekat dengan lensa, objek tersebut tidak bisa fokus. Untuk mengatasi masalah ini, bila memakai kamera saku, fotografer dapat mengaktifkan fitur pemotretan makro, bila tersedia dalam kameranya, yang biasanya ditandai dengan simbol bunga, maka lensa kamera tersebut bisa menyesuaikan fokus dengan jarak objek ke lensa yang cukup dekat. Namun tentu saja masih ada jarak fokus minimal saat fitur ini diaktifkan. Untuk fitur makro ini, sayangnya masih belum didapati pada kamera telpon genggam. Namun kesalahan tersebut masih dapat diatasi dengan mengatur kembali jarak pengambilan foto agar objek tidak terlalu dekat jaraknya dengan lensa kita.

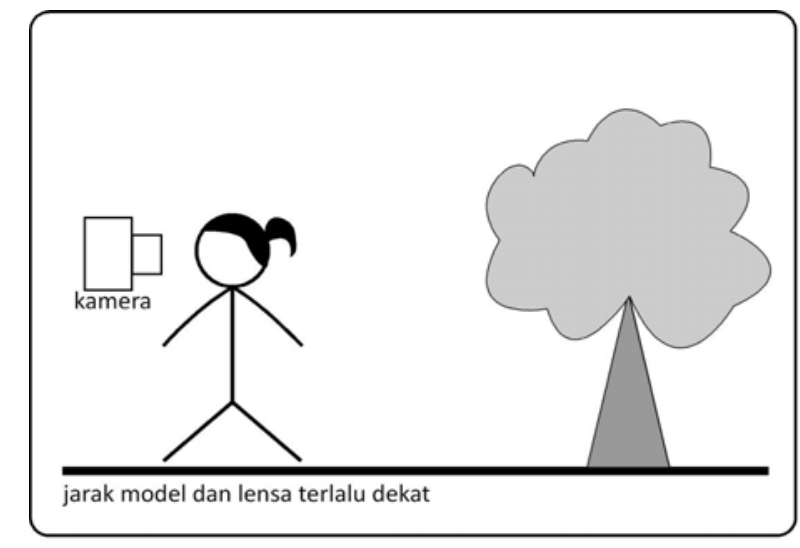

Gambar 3 Posisi Objek terlalu Dekat dengan Lensa Kamera

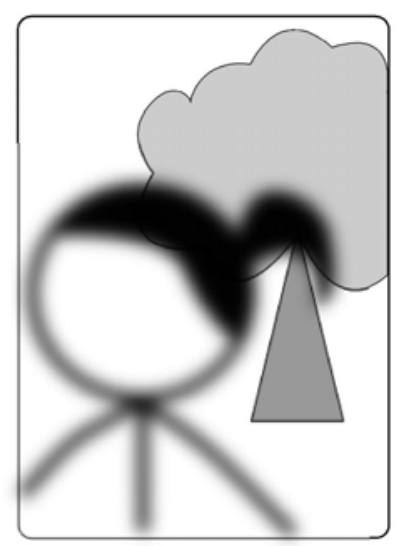

Gambar 4 Hasil Foto Objek Blur

Kondisi kedua bila objek foto terlihat buram, tapi latar belakang fokus, bila tampilan foto dianalisa, objek tersebut tidak terlalu dekat dengan kamera dan bahkan bisa terlihat cukup utuh dalam bidang foto, maka yang terjadi dalam kondisi tersebut adalah objek yang terekam dalam foto saat itu, sedang bergerak. Sehingga situasi saat pemotretan adalah saat menekan tombol kamera, diafragma terbuka dengan shutter speed yang lebih lambat dibanding gerakan objek sehingga saat pengambilan foto, objek yang sedang terfoto, terekam beserta gerakannya, sehingga menghasilkan gambar yang bertumpuk sesuai gerakan objek dan hasilnya terlihat buram, tidak fokus atau tidak tajam. Karenanya latar belakang yang terekam terlihat tajam atau fokus karena latarnya diam tidak bergerak. Misalnya dalam kasus, ada anak kecil sedang lari didepan sebuah pohon, karena anaknya melakukan gerakan maka dia terlihat bergeser, sedangkan pohonnya tetap diam dan jelas. 


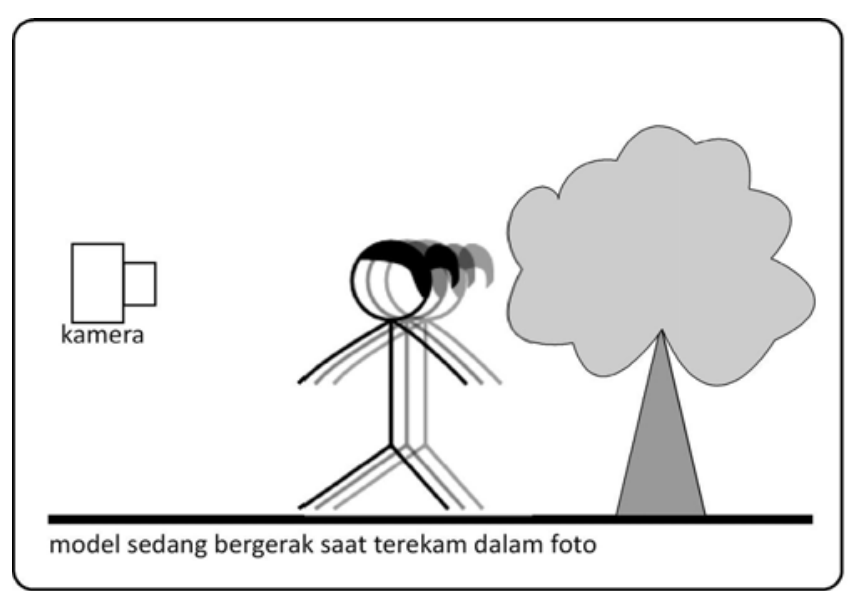

Gambar 5 Saat pemotretan, model sedang bergerak

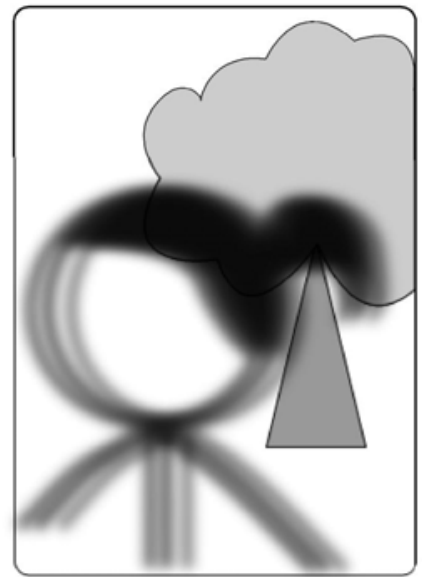

Gambar 6 Hasil foto blur berlapis

Untuk mengatasi masalah ini, bila menggunakan kamera yang shutter speed-nya bisa diubah, fotografer cukup mengatur agar waktu yang dibutuhkan saat pemotretan berlangsung bisa lebih cepat atau sama dengan kecepatan gerak si objek. Namun bila kamera yang dipakai tidak memiliki fitur tersebut, dibutuhkan kerjasama dengan model yang berpose, untuk diam sesuai waktu pengambilan gambar, terutama dalam penggunaan kamera telpon genggam. Sehingga bisa diakui bahwa kekurangan dari kamera-kamera otomatis adalah sulit mengabadikan momen saat objek utama, cukup aktif bergerak. Salah satu cara untuk mengatasi masalah ini adalah dengan memakai flash sehingga cahayanya yang cukup terang dan muncul sesaat itu bisa merekam satu momen gerakan model dengan cahaya kilat itu. Sehingga gerakan lain dari model tidak terlalu jelas terekam dalam kamera, namun hanya satu momen saat flash tersebut menyala.

'Hasil foto yang bernuansa kekuningan'. Banyak orang mengalami kejadian ini dan mungkin sempat kebingungan pada awalnya, namun kemudian mereka makin terbiasa dan bisa mengambil kesimpulan bahwa saat mereka berada di ruangan yang bernuansa lampu atau interiornya agak kekuningan, otomatis hasil fotonya juga kekuningan. Dalam hal ini, memang situasi dimana suatu ruangan mendapat karakter cahaya yang 'berwarna' dan bukan netral, akan merekam karakter warna tersebut dalam foto yang diambil. Situasi dan kondisi seperti ini sangat sering terjadi terutama bila pengambilan foto dilakukan pada sebuah kafe, atau restoran, dan dengan pencahayaan yang berwarna itu, otomatis karakter warna kulit atau warna asli dari objek asli yang difoto akan terkontaminasi warna itu. Misalnya kulit model akan tampak kekuningan, warna cangkir keramik berwarna putih terlihat kekuningan juga.

Bila mengalami kejadian seperti ini yang harus dilakukan adalah mencari fitur White Balance dalam kamera yang digunakan. Bahkan kamera dalam telpon genggam pun banyak yang sudah dilengkapi dengan fitur ini. Dengan memilih pilihan AWB atau auto white balance sebagian besar dari permasalahan kontaminasi warna ini cukup teratasi, karena fitur ini memungkinkan fotografer memotret dengan segala kondisi pencahayaan dengan pengukuran yang membaca semua benda putih tampak mendekati putih. Namun tentu ada kelemahannya sebab kadar warna dari masing-masing situasi belum tentu sama.

Untuk lebih presisi, bisa digunakan pilihan yang lebih spesifik untuk karakter warna yang lebih spesifik pula. Pilihan tungsten untuk mengkoreksi warna dengan karakter cahaya tungsten atau yang kekuning-kuningan, misalnya lampu halogen, tata cahaya di lobi hotel, di cafe atau di ballroom hotel. Sehingga semua benda yang terfoto bisa tampak semirip mungkin dengan warna aslinya. 
Untuk hasil foto dengan karakter yang tampak bernuansa kehijau-hijauan, ini disebabkan karena pemotretan dilakukan dengan sumber cahaya yang berkarakter fluorescent atau kondisi dengan pencahayaan dengan lampu neon. Misalnya saat pemotretan dalam ruang tamu berlampu neon, atau dalam suasana sebuah kantor atau kelas. Warna kulit model dan benda berwarna putih akan berkarakter kehijauan bila mendapat sumber cahaya dari neon ini. Untuk mengatasi kontaminasi warna hijaunya, maka fitur pilihan fluorescent yang harus dipilih saat pemotretan berlangsung. Dengan fitur $A W B$ atau fitur auto white balance tersebut diharapkan semua hasil foto akan terekam dengan warna yang sesuai dengan aslinya.

\section{SIMPULAN}

Fotografi dulunya merupakan hobi dari sebagian masyarakat dikarenakan peralatan yang dipakai tergolong cukup mahal, dan untuk dapat memakai kamera harus belajar khusus bagaimana cara kerja dan tehnik-tehnik dasarnya untuk bisa menghasilkan foto yang bernilai, karya fotografi pun dulunya dinikmati dalam suatu forum dan kelompok khusus, bahkan dihitung sebagai suatu karya seni. Namun semakin berkembangnya jaman, sekarang fotografi dikenal diseluruh lapisan masyarakat umum, bahkan hasil karya foto sekarang bergeser fungsinya dari sebuah karya seni semakin lama menjadi sarana untuk bercerita oleh banyak orang saat ini. Untuk menggambarkan kegiatan hariannya, kegiatan liburannya, bercerita tentang keluarganya dan sebagainya, yang di pamerkan melalui situssitus seperti Facebook, Twitter, atau melalui Blackberry.

Namun tanpa berbekal teori dan tehnik fotografi, banyak orang yang hanya bisa memotret tanpa bisa menghasilkan foto sesuai harapannya. Sehingga sangat penting untuk para 'fotografer' yang memotret dengan kamera sederhana, untuk mengetahui hal-hal dasar untuk mengatasi permasalahan yang paling sering timbul dalam pemakaian kamera-kamera tanpa fitur yang lengkap dan tanpa pengetahuan tehnik yang teoritis. Terutama untuk mengatasi kekurangan dari kamera sederhana yang digunakan, sehingga semua momen yang diabadikan akan tersimpan dengan semaksimal mungkin tanpa membuang momen tersebut karena hal sepele misalnya, objeknya bergerak, atau objek terlalu dekat, dan sebagainya.

\section{DAFTAR PUSTAKA}

Langford, M. (2000). Basic Photography. Oxford: Focal Press

London, B., Upton, J., Stone, J., Kobre, K., Brill, B. (2005). Photography. New Jersey: Pearson Education, Inc. 